\title{
Comparison of Growth Performance of 'Common Catfish Ameiurus melas, Rafinesque1820', Reared in Pond and in Recirculating Aquaculture System
}

\author{
Alessandra Roncarati ${ }^{1}$, Oliviero Mordenti ${ }^{2}$, Luca Stocchi ${ }^{3}$ and Paolo Melotti ${ }^{1}$ \\ ${ }^{1}$ School of Biosciences and Veterinary Medicine, Camerino University, Matelica, Italy \\ ${ }^{2}$ Department of Veterinary Medical Sciences (DIMEVET), University of Bologna, Ozzano Emilia, Bologna, Italy \\ ${ }^{3}$ Department of Agricultural and Food Sciences (DISTAL), University of Bologna, via del Florio 2, Ozzano dell'Emilia (BO), Italy
}

\begin{abstract}
A trial was conducted to evaluate the growth performance and survival of common catfish, Ameiurus melas. A total of 54,420 catfish juveniles $(5.1 \pm 1.2 \mathrm{~g} ; 6 \pm 1 \mathrm{~cm})$ were reared in two groups: PN group, represented by 3-1,000 $\mathrm{m}^{2}$ ponds; RC group composed by $3-2 \mathrm{~m}^{3}$ indoor tanks working in closed recirculated system. In these two groups, catfish were reared at two different densities $\left(P N=15\right.$ fish $\mathrm{m}^{3} ; \mathrm{RC}=1,570$ fish $\left.\mathrm{m}^{3}\right)$ for 181 days. The main water physico-chemical parameters were monitored and the main blood metabolites and growth performances were evaluated. Catfish exhibited a final mean body weight similar in the two groups (PN=142.7 $\pm 30 \mathrm{~g} ; \mathrm{RC}=151.5 \pm$ $34 \mathrm{~g})$. The survival rate was high for both PN $(86.6 \%)$ and RC (99\%). A very high stocking density was reached in the RC system $\left(235.5 \mathrm{kgm}^{3}\right)$. The presence of multi-trays in the RC tanks may be helped the specimens to reduce aggressiviness and territorial competition as demonstrated by blood metabolites which did not affect by rearing conditions. This trial showed that common catfish can be successfully cultured in indoor systems without negatively affecting productive performances (growth and survival) and the natural resources.
\end{abstract}

Keywords: Ameiurus melas; Rearing techniques; Recirculating water system; Catfish pond culture; Growth performance

Abbreviations: ANOVA: Analysis of variance; B.W.: Body weight; DO: Dissolved oxygen; K: Condition factor; FCR: Food conversion rate; NO2-N: Nitrite-nitrogen; NO3-N: Nitrate-nitrogen; RAS: Recirculating Aquaculture System; SD: Standard deviation; SGR: Specific growth rate; TAN: Total Ammonia Nitrogen; TL: Total length; GOD-PAP: Glucose oxidase and 4-aminoantipyrine; CHODPOD: Cholesterol oxidase and peroxidase; GPO: Glycerol-3-phosphate oxidase; LDH: Lactate dehydrogenase; SCE: Scandinavian Committee on Enzymes method; AST: Aspartate aminotransferase; ALT: Alanine aminotransferase; IFCC: International Federation of Clinical Chemistry method; CK: Creatine kinase; UV: Ultraviolet method

\section{Introduction}

In Italy, the rearing of the 'black bullhead or common catfish Ameiurus melas, Rafinesque 1820', an allochthonous fish species introduced in Italy at the beginning of $20^{\text {th }}$ century, represents one of the most traditional systems of farming in the northern freshwater territories. This activity began in the lower Modena Province in the '70s from juveniles collected in nature. After a short training, the practice has become widespread in the regions of Emilia Romagna, Veneto and Lombardia going to occupy marginal areas of many farms involved in agriculture, in perfect balance with the other livestock products and vegetables.

Until the first ' 90 s, the common catfish production was well consolidated with over 3,000 t/year, especially in Emilia Romagna, Lombardia and Veneto where this fish species had a tradition as food supply and sport fishing. Since 1994, a drastic reduction, caused by an herpesvirus first isolated in two different catfish farms $[1,2]$, took place until to touch to $200 \mathrm{t}$ in 2012 [3]. In order to avoid virus attack, at moment, growth of this species could be achieved only using groundwater, capable of maintaining water temperatures below 23$24^{\circ} \mathrm{C}$ in the summer months [3]. Under these conditions, common fattening phase can therefore be implemented successfully starting from non native fingerlings imported from Hungary $[4,5]$. Plants involved in common catfish production can be classified in the semi-intensive category, with productions ranging between 1.5 and $4 \mathrm{t} / \mathrm{ha} /$ year. The balanced diet is widely adopted and the food conversion index ranges between 1.2 and 1.5:1. The surface area of catfish farms ranges between 5 and 7 ha with a total annual production of $22-50 t$ [6].

In an effort to exclude pathogens from the water environment of black bullhead culture and support some Italian farmers, researchers are evaluating alternative approaches to traditional pond culture. One of these production systems is represented by the recirculating aquaculture system (RAS) where the entire fattening cycle of the catfish is carried out under closed-cycle conditions until market size.

In the last times, RASs have known a large diffusion for many fish species as motivation for the development of sound environmental friendly aquaculture production systems. RASs offer advantages in terms of water reuse and consequent reduced water consumption, improved opportunities for waste management and nutrient recycling and for a better hygiene and disease management and biological pollution control [7]. In the present study, a fattening trial of common catfish was carried out until market size in order to compare growth

*Corresponding author: Alessandra Roncarati, School of Biosciences and Veterinary Medicine, University of Camerino, Viale Circonvallazione 93-95, 62024 Matelica, Italy, Tel: +39 0737 403416; Fax : +39 0737 403410; E-mail: alessandra.roncarati@unicam.it

Received November 27, 2013; Accepted December 30, 2013; Published January 15,2014

Citation: Roncarati A, Mordenti O, Stocchi L, Melotti P (2014) Comparison of Growth Performance of 'Common Catfish Ameiurus melas, Rafinesque1820', Reared in Pond and in Recirculating Aquaculture System. J Aquac Res Development 5: 218 doi:10.4172/2155-9546.1000218

Copyright: (c) 2014 Roncarati A, et al. This is an open-access article distributed under the terms of the Creative Commons Attribution License, which permits unrestricted use, distribution, and reproduction in any medium, provided the original author and source are credited. 
Citation: Roncarati A, Mordenti O, Stocchi L, Melotti P (2014)Comparison of Growth Performance of 'Common Catfish Ameiurus melas, Rafinesque1820', Reared in Pond and in Recirculating Aquaculture System. J Aquac Res Development 5: 218 doi:10.4172/2155-9546.1000218

Page 2 of 6

performance obtained in conventional open ponds, supplied with well water, and in tanks, working in recirculating aquaculture system.

\section{Materials and Methods}

For the trial, common catfish fingerlings (mean body weight $5.1 \pm$ $1.2 \mathrm{~g}$, mean length $6 \pm 1 \mathrm{~cm}$ ) were chosen in March 2012 from a lot of specimens imported from a Central European fish farm. In total, 54,420 catfish juveniles were subdivided in two groups subject to be reared in different environmental conditions: earthen basins and indoor tanks.

The first group (PN) was reared in 3-1,000 $\mathrm{m}^{2}$ ponds, $1.2 \mathrm{~m}$ deep (1.0 $\mathrm{m}$ water column), supplied with well water, which were located in a fish farm. Two aerators were present in each pond. Oxygen device was also introduced in all the basins and started to work when water dissolved oxygen decreased to below $6 \mathrm{mg} / \mathrm{L}$. Water exchange was fixed at $2-41 / \mathrm{sec} / \mathrm{ha}$.

The second group (RC) was reared in $3-2 \mathrm{~m}^{3}$ indoor fibreglass tanks each associated to a recirculating filtration system provided with pumping, equipped with Venturi's Tube as air injector, a control and regulation of water temperature, skimmer, UV lamp apparatus, ozone system. The ozone generator converted a fraction of the pure oxygen feed gas to ozone that was subsequently transferred to water within the system. Photoperiod was not manipulated.

All the indoor tanks were equipped with two structures, each composed by five round overlapping trays, made of rigid plastic, measuring $80 \mathrm{~cm}$ diameter and $12 \mathrm{~cm}$ distant one from the other, with a surface area of $0.5024 \mathrm{~m}^{2}$ per tray. Every tray was perforated to allow free passage of water; all the five planes of the structure were joined by an iron steel in the central position and fixed with bricks (Scheme 1).

The initial number of catfish was selected based on the expectation of final loads of more than $30 \mathrm{~kg} \mathrm{~m}^{3}$ and $2 \mathrm{~kg} \mathrm{~m}^{3}$ in the RC and PN groups, respectively. After a $2-15$ weeks adaptation period in the culture systems, the trial started on 3 April 2012 and lasted 181 days until 1 October 2012 for both groups. The main farming parameters adopted in the experimental design of the trial are reported in Table 1. All fish were provided with the same feeding programme, based on a commercial extruded feed (proximate composition on wet weight basis: protein $40 \%$; lipid $14 \%$; ash $8.5 \%$; crude fibre $4 \%$ ) at a daily ratio adjusted between $1.5 \%$ and $2 \%$ of fish body weight, in relation to water temperature. When the feed was placed into the feeder each day, tanks were inspected for dead specimens, which were immediately removed. After 3 months of fattening, the two groups were graded.

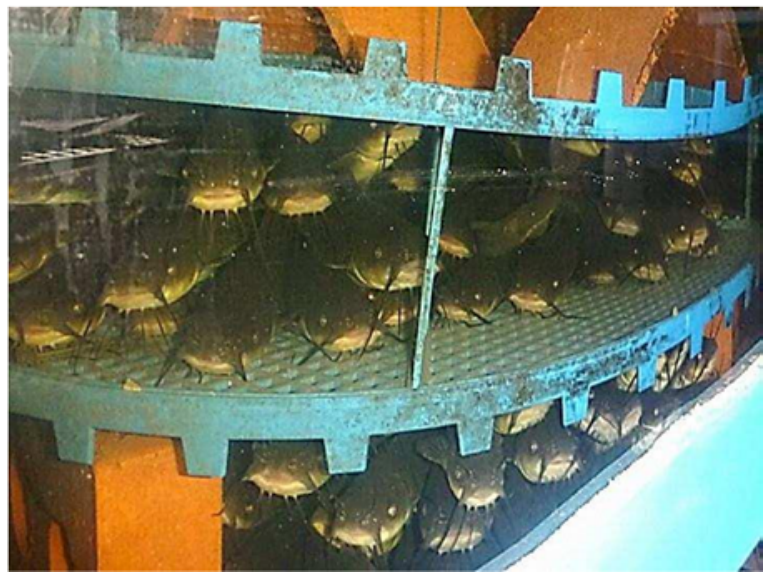

Scheme 1: Specimens of common catfish reared in RC thesis

\begin{tabular}{|l|c|c|}
\hline & PN & RC \\
\hline Rearing technique & Ponds & Indoor tanks \\
\hline Size of rearing per each basin $(\mathrm{m} 3)$ & 1,000 & 2 \\
\hline Replicates per treatment $(\mathrm{n})$. & 3 & 3 \\
\hline Origin of water & well water & well water \\
\hline Range of water temperature $\left({ }^{\circ} \mathrm{C}\right)$ & $12-30$ & $19-22$ \\
\hline Water flow rate $(\mathrm{l} / \mathrm{sec} / \mathrm{t})$ & $2-4$ & - \\
\hline Initial weight $(\mathrm{g})$ & $5.1 \pm 1.2$ & $5.1 \pm 1.2$ \\
\hline Initial length $(\mathrm{cm})$ & $6.8 \pm 1$ & $6.8 \pm 1$ \\
\hline Condition factor $(\mathrm{K})$ & 1.62 & 1.62 \\
\hline Initial stocking density $(\mathrm{n} . \mathrm{fish} / \mathrm{m} 3)$ & 15 & 1,570 \\
\hline Initial stocking density $(\mathrm{kg} / \mathrm{m} 3)$ & 0.0765 & 8,007 \\
\hline Feeding ratio $(\%$ b.w./d) & $0.5-3.5$ & $3-4$ \\
\hline N. feed administration $(\mathrm{n} . \mathrm{meals} / \mathrm{d})$ & 2 & 2 \\
\hline Aeration/oxygen & Present & Present \\
\hline Length of the trial $($ days $)$ & 181 & 181 \\
\hline Expected final density $\left(\mathrm{kg} / \mathrm{m}^{3}\right)$ & $>2$ & $>30$ \\
\hline
\end{tabular}

Table 1: Main farming parameters adopted in the two fattening trials of common catfish.

Every 30 days, 30 fish from each group were individually weighed to 1 the nearest $0.1 \mathrm{~g}$ with electronic balance scales (mod. Mettler 5000, Mettler Toledo International, Novate Milanese, Italy), and total body length (from the most anterior extremity to the caudal fin squeezed to give the maximum length measurement) was measured to the nearest millimetre using an ictiometer. At the beginning and at the end of the trial, condition factor $(\mathrm{K})$ was calculated according to the formula $\mathrm{K}=(\mathrm{BW} \times 100$ $\mathrm{TL}$ to the power -3 ) where $\mathrm{BW}=$ body weight and $\mathrm{TL}=$ total length (8).

The main water physico-chemical parameters were monitored in both the groups (PN, RC). Temperature, dissolved oxygen (DO) and $\mathrm{pH}$ were daily measured using portable electronic devices (YSI mod. 55 and 60 ) in the morning (8 a.m.). Total ammonia nitrogen (TAN), nitrite-nitrogen $(\mathrm{NO} 2-\mathrm{N})$ and nitrate-nitrogen $(\mathrm{NO} 3-\mathrm{N})$ were checked weekly, collecting $500 \mathrm{cc}$ of water per thesis for laboratory-based determination of using a spectrophotometer (Hach mod-2005, Hach Company, Loveland, USA) according to APHA methods [8,9].

Blood sampling of PN and RC groups was performed after 90 days of the trial ( 5 fish per pond and 5 per tank), following the same procedure for blood collecting suggested in literature for monitoring blood parameters and fish welfare [10-12] and repeated during the last days of the trial. The blood was left to coagulate at room temperature and then centrifuged at $2,500 \times \mathrm{g}$ for 10 minute. The following serum parameters were immediately determined spectrophotometrically [13]: glucose (glucose oxidase and 4-aminoantipyrine (GODPAP) Trinder method); total cholesterol (Cholesterol oxidase and peroxidase (CHOD-POD) Trinder method); triglycerids (glycerol3-phosphate oxidase (GPO) colorimetric method); total protein (Biurete colorimetric method);lactate dehydrogenase (LDH) (UV optimised Scandinavian Committee on Enzymes (SCE) method); transaminases, such as aspartate aminotransferase 1 (AST) and alanine 2 aminotransferase (ALT) (UV optimised International Federation of Clinical Chemistry and Laboratory Medicine (IFCC) method); and creatine kinase (CK) (UV method). The final results of water chemical parameters, growth performances, indices and blood metabolites were submitted to analysis of variance (ANOVA) using the SAS General Model procedure in order to detect differences between the two groups. The means were separated by a Student Newmann Keuls test [14]. Differences were considered significant at $\mathrm{P}<0.01$ and $\mathrm{P}<0.05$. 


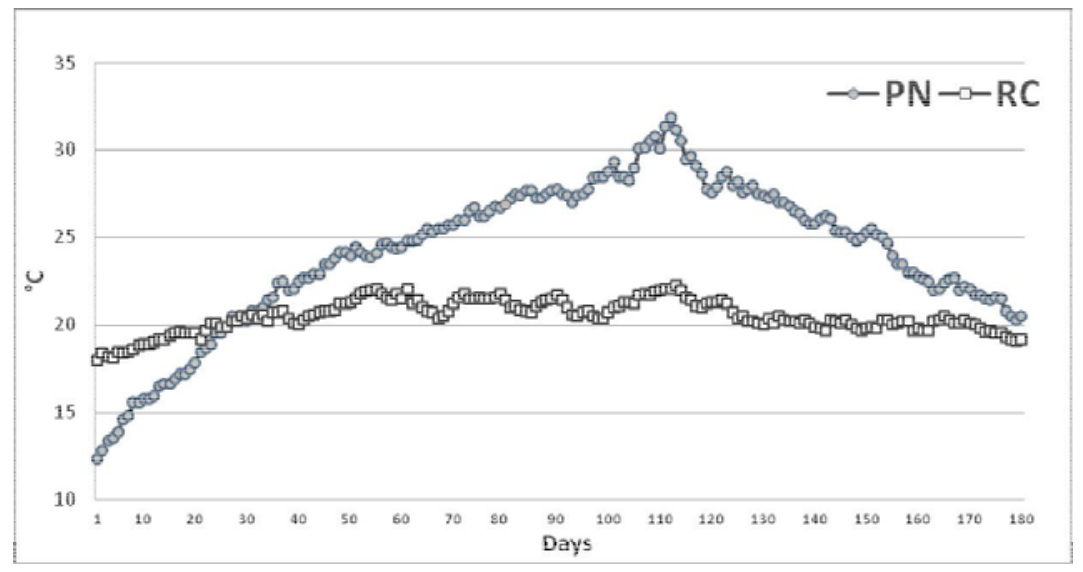

Figure 1: Trend of water temperature recorded in $\mathrm{PN}$ and $\mathrm{RC}$ groups employed to rear common catfish.

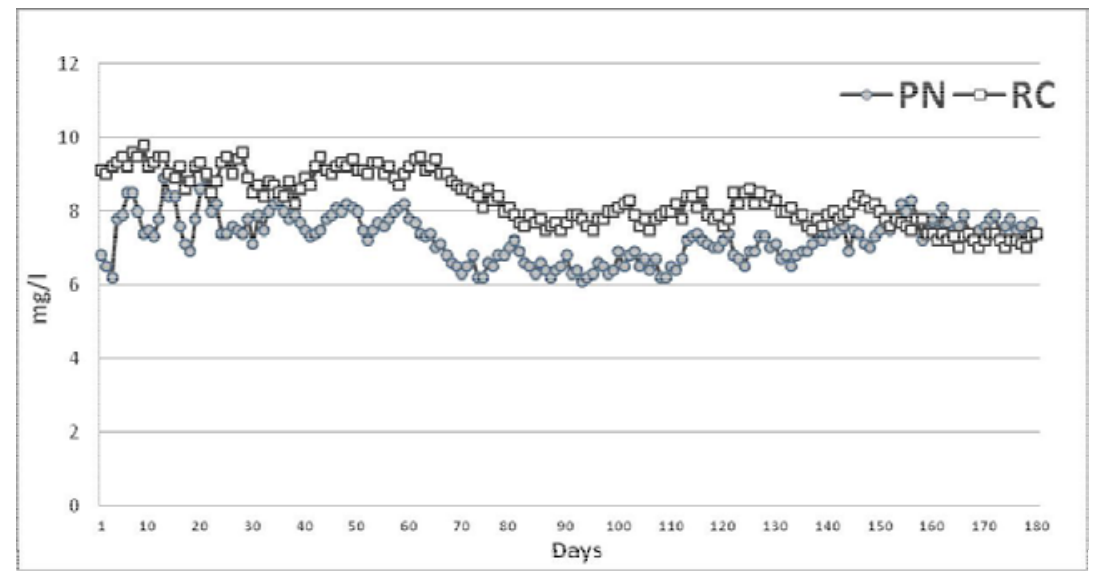

Figure 2: Trend of water dissolved oxygen recorded in PN and RC groups employed to rear common catfish.

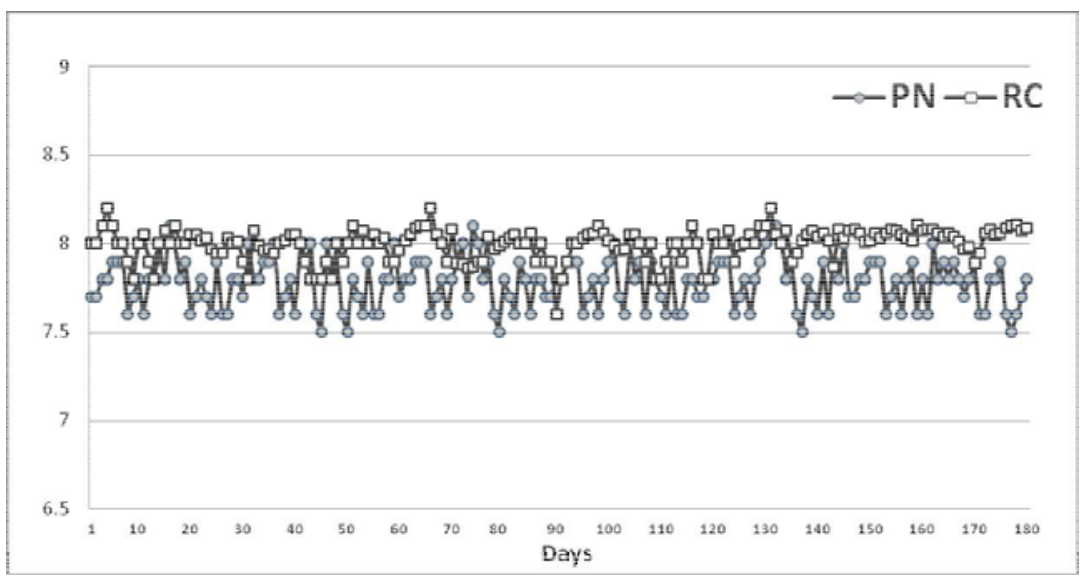

Figure 3: Trend of water $\mathrm{pH}$ recorded in $\mathrm{PN}$ and $\mathrm{RC}$ groups employed to rear common catfish.

\section{Results}

The physico-chemical parameters of the waters controlled in the two systems were reported in Figures 1-4, including the trend in mean values for temperature, $\mathrm{DO}, \mathrm{pH}$ and nitrogen compounds. Water temperature showed the highest fluctuations in PN groups $(24.11 \pm$ $4.19^{\circ} \mathrm{C}$ ) particularly during the initial period of the trial (April) and in the summer whereas in RC tanks the average temperature was 20.48 $\pm 0.9^{\circ} \mathrm{C}$ (Figure 1). DO ranged between $7.28 \pm 0.62 \mathrm{mg} / \mathrm{L}$ in $\mathrm{PN}$ and $8.30 \pm 0.71 \mathrm{mg} / \mathrm{L}$ in $\mathrm{RC}$ group (Figure 2). $\mathrm{pH}$ showed average values of $7.78 \pm 0.14$ in PN basins and $7.99 \pm 0.08$ in RC group (Figure 3). TAN levels stayed at $0.5 \pm 0.1 \mathrm{mg} / \mathrm{L}$ and $0.2 \pm 0.04 \mathrm{mg} / \mathrm{L}$ in $\mathrm{PN}$ and RC, respectively. N-NO2 were significantly higher in PN group $(0.075 \pm$ $0.02 \mathrm{mg} / \mathrm{L})$ compared to and RC tanks $(0.027 \pm 0.005 \mathrm{mg} / \mathrm{L})$. The same 


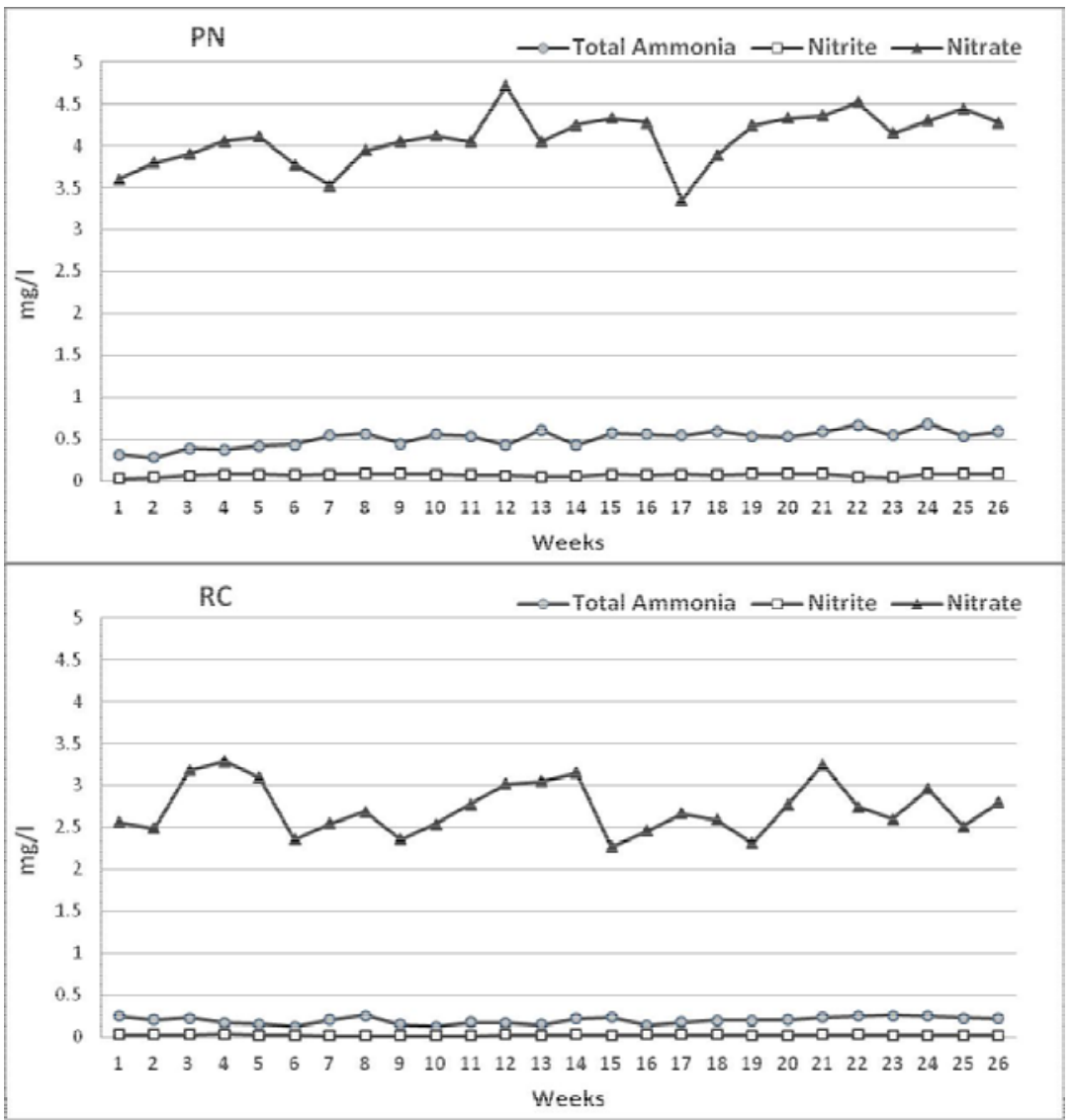

Figure 4: Trend of water nitrogen compounds (TAN, N-NO2, N-NO3) recorded in PN (upper) and RC (lower) groups employed to rear common catfish.

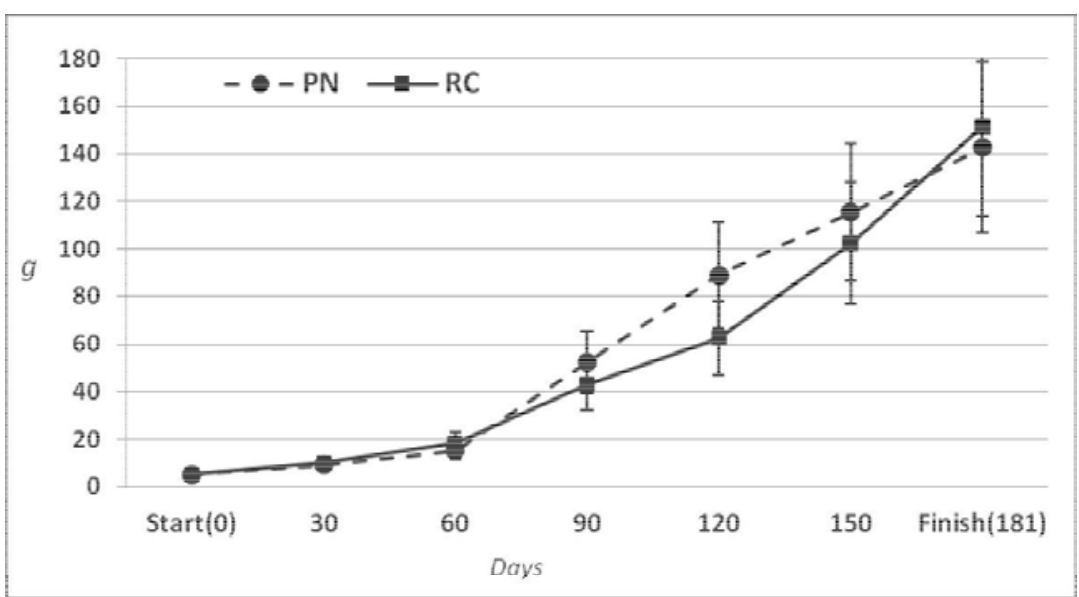

Figure 5: Trend of mean body weight of common catfish reared in PN and in RC groups.

notable difference was observed in N-NO3 with an average value (4.09 $\pm 0.88 \mathrm{mg} / \mathrm{L})$ in $\mathrm{PN}$ higher than RC water $(2.73 \pm 0.30 \mathrm{mg} / \mathrm{L})$ (Figure 4$)$.

Trend of mean body weight of common catfish reared in the two systems is presented in Figure 5; no significant differences were noted between final mean body weight of PN and RC groups. Growth performance, size and specific growth rate are reported in Table 2; data did not show significant differences between the groups. Food conversion rate did not result notably different between the thesis. The survival rate was significantly higher in the RC group (99\%) than in the PN group (86.6\%). Table 3 presents the blood parameter data determined at 90 and 180 days of the trial in the two catfish groups (PN, $\mathrm{RC}$ ). There was no difference in mean glucose values and the levels of triglyceride, cholesterol, total protein, transaminases (AST and ALT), $\mathrm{LDH}$ and $\mathrm{CK}$ showed no significant differences between the catfish. 


\begin{tabular}{|l|c|c|}
\hline & PN & RC \\
\hline Final mean weight $(\mathrm{g})$ & $142.7 \pm 30$ & $151.5 \pm 34$ \\
\hline Final mean length $(\mathrm{cm})$ & $22 \pm 2$ & $22.4 \pm 2$ \\
\hline Condition factor $(\mathrm{K})$ & 1.34 & 1.35 \\
\hline Final stocking density $(\mathrm{kg} / \mathrm{m} 3)$ & 1.85 & 235.5 \\
\hline Specific growth rate $(\%)$ & $1.84 \pm 0.5$ & $1.87 \pm 0.3$ \\
\hline Feed conversion rate & $1.2: 1$ & $1.1: 1$ \\
\hline Survival rate $(\%)$ & 86.6 & 99 \\
\hline
\end{tabular}

Table 2: Results obtained at the end of the common catfish growth in ponds (PN) and tanks working in recirculated aquaculture system (RC).

\begin{tabular}{|l|l|l|}
\hline & PN & $R C$ \\
\hline Glucose $\left(\mathrm{g} \mathrm{L}^{-1}\right):$ & & \\
\hline $90 \mathrm{~d}$ & $1.78 \pm 0.13$ & $1.86 \pm 0.23$ \\
\hline $180 \mathrm{~d}$ & $1.72 \pm 0.16$ & $1.90 \pm 0.14$ \\
\hline Triglycerides $\left(\mathrm{g} \mathrm{L}^{-1}\right):$ & & \\
\hline $90 \mathrm{~d}$ & $2.60 \pm 0.27$ & $2.63 \pm 0.19$ \\
\hline $180 \mathrm{~d}$ & $2.68 \pm 0.15$ & $2.72 \pm 0.28$ \\
\hline Total cholesterol $\left(\mathrm{g} \mathrm{L}^{-1}\right):$ & & \\
\hline $90 \mathrm{~d}$ & $3.12 \pm 0.65$ & $2.72 \pm 0.52$ \\
\hline $180 \mathrm{~d}$ & $2.98 \pm 0.29$ & $2.82 \pm 0.42$ \\
\hline Total protein $\left(\mathrm{g} \mathrm{L}^{-1}\right):$ & & \\
\hline $90 \mathrm{~d}$ & $3.11 \pm 0.6$ & $2.72 \pm 0.5$ \\
\hline $180 \mathrm{~d}$ & $2.98 \pm 0.3$ & $2.83 \pm 0.4$ \\
\hline $\mathrm{LDH}\left(\mathrm{U} \mathrm{L}^{-1}\right):$ & & \\
\hline $90 \mathrm{~d}$ & $40.40 \pm 5.3$ & $42.3 \pm 6.6$ \\
\hline $180 \mathrm{~d}$ & $40.50 \pm 7.2$ & $44.6 \pm 5$ \\
\hline AST $\left(\mathrm{U} \mathrm{L} \mathrm{L}^{-1}\right):$ & & \\
\hline $90 \mathrm{~d}$ & $93.8 \pm 7.4$ & $92.8 \pm 9.9$ \\
\hline $180 \mathrm{~d}$ & $103.6 \pm 12.9$ & $102 \pm 10$ \\
\hline ALT $\left(\mathrm{U} \mathrm{L}^{-1}\right):$ & & \\
\hline $90 \mathrm{~d}$ & $120.6 \pm 20.5$ & $125.7 \pm 19$ \\
\hline $180 \mathrm{~d}$ & $123.4 \pm 13.6$ & $119.2 \pm 16$ \\
\hline $\mathrm{CK}\left(\mathrm{U} \mathrm{L}^{-1}\right):$ & $339.4 \pm 80.5$ & $406.2 \pm 55.6$ \\
\hline $90 \mathrm{~d}$ & $450.6 \pm 75.3$ & $435.8 \pm 60.5$ \\
\hline $180 \mathrm{~d}$ & & \\
\hline & & \\
\hline
\end{tabular}

Table 3: Blood parameters (mean \pm S.D.) of common catfish reared in $\mathrm{PN}$ and $\mathrm{RC}$ groups, determined at 90 days (d) and at the end of trial (180 days).

\section{Discussion}

This study was focalized on 'common catfish Ameiurus melas' reared in conventional earthen basins and in tanks provided with water in recirculated water system. In the wild, the common catfish is considered a species tolerant to water pollution, turbidity, low oxygen concentration, elevated temperatures and a range of $\mathrm{pH}$ values [15], but in rearing conditions the water quality becomes important to guarantee the fish productivity [16]. In the present study, the physicochemical parameters of the waters controlled in the two systems always stayed within the range considered optimal for catfish [17] although high fluctuations were showed in the PN group. In the RC group, maximum water temperature was not characterised by any significant fluctuations in temperature whereas in the $\mathrm{PN}$ basins water temperature was subjected to seasonal and daily fluctuations. In a study about rearing of European catfish (Silurus glanis), comparing open and enclosed systems, both systems resulted to be able to maintain good water quality but the recirculating system significantly 1 showed higher water temperatures and achieved the best fish growth [18]. In the RC group, the lack of natural productivity in this system and absence of algal blooms can have contributed to maintain the optimal oxygen concentration in water all the time of the trial. After the administration of feed, dissolved oxygen showed a reduction, but it did not lower under $5.5 \mathrm{mg} / \mathrm{L}$. With the recirculation treatment, the water quality parameters were maintained at acceptable levels for fish growth over the 24 weeks of trial. This was mainly attributed to the combined treatment by the biological filter and was further demonstrated by the lower trophic status in the recirculating basins, as compared to the ponds. In other studies, RAS significantly purifies the water reused, with a percent removal of $19.5 \%$ for the TAN and an increased DO within a range of 4.41-7.91 $\mathrm{mg} / \mathrm{L}$ [19].

In channel catfish (Ictalurus punctatus) ponds, it has been reported that most of the oxygen (76.9\%) is produced by phytoplankton photosynthesis [20]. Thus, a pond with higher phytoplankton levels usually attains a higher daily DO. Nevertheless, in the current study, the DO was monitored in the morning when the algal photosynthesis was at a low rate. After a night of respiration, the DO in pond would be at its lowest level at dawn and would gradually recover in the daytime due to photosynthesis. The RAS provides better environmental conditions year-round, contributes to the health of the fish and minimises the FCR, thus improving the feeding efficiency [21]. In another study [22], a basic trend was that the feed intake quantity decreased and the FCR was higher in the ponds than in the recirculating tanks. Lin et al. [23] have reported a lower FCR in an RAS (1.65) than in the control (2.25) when they utilised a combined wetland unit to recirculate wastewater from a shrimp culture tank. Other Authors [24] have demonstrated a favourably lower FCR in recirculating pond (1.43) than in static pond (2.27) when they integrated vertical-flow into an outdoor RAS for culturing catfish (I. punctatus and Megalobrama amblycephala). In a paper about growth performances of sunshine bass (Morone chrysops $\times$ Morone saxatilis), no effect was found comparing three different rearing conditions (concrete basins, raceways and natural ponds) nor differences regarding the proximate composition and fatty acid profile of the fillet [25]. In the present study, in the RC tanks, the high water transparency assured to visualize feed fast avoiding to affect water quality due to increase of nitrogen compounds. In the RC group, catfish exhibited the same market size of the fish in PN ponds, despite higher stocking density adopted in the first system.These results were surprising because catfish juveniles are known to be fairly aggressive and cannibalistic during the first growing phase and grading is commonly employed in outdoor ponds and/or cages to reduce the impact of cannibalism [26].

High densities are known to negatively affect catfish growth including general appetite reduction, increased aggression, poor water quality and increased competition for food. However, some authors, evaluating the influence of density on the welfare of juvenile African catfish in a growth stage of 100-1500 g, showed that the effects of stocking density are not uniform throughout the growth cycle [12]. In the present study, no effect on haematochemical parameters was showed; catfish in RC tanks did not display aggressive behaviour. In most fish species, growth rate is inversely related to stocking density and a significant increase in plasma cholesterol and albumin, indicated reduced food utilization. The lack of significant differences in blood parameters may be the result of recovery, as it has been previously reported for other species, like O. aureus, Salvenius alpinus and Dicentrarchus labrax, that an increase in fish density up to a certain level improves growth, probably by reducing aggressiveness or due to a schooling behaviour. The survival rate was particularly high in the RC group but it was also satisfactory in the PN group. Presumably, an important factor which could have contributed to achieve these satisfying results was represented by the multi-trays positioned into the RC tanks. The multi-trays had the advantage to let to use the water column totally; the five planes of the structure, located in the central 
Citation: Roncarati A, Mordenti O, Stocchi L, Melotti P (2014)Comparison of Growth Performance of 'Common Catfish Ameiurus melas, Rafinesque1820', Reared in Pond and in Recirculating Aquaculture System. J Aquac Res Development 5: 218 doi:10.4172/2155-9546.1000218

Page 6 of 6

position of each tank, offered refuge to catfish which were free to move inside and outside.

\section{Conclusion}

This research aimed at showing the suitability of recirculated water system as possible rearing technique alternative to the open ponds for common catfish saving well water and energy to pump it and avoid viral attacks. The results obtained in this trial showed that common catfish can be successfully cultured in indoor systems without negatively affecting productive performances (growth and survival) and the natural resources.

\section{Acknowledgements}

We are very grateful to Mr. Giovanni Magnanini and staff by Acqua \& Co for their precious collaboration in technical assistance for the recirculation wate system device. Further, we wish to thank Mr. Gianni and Luca Ferioli for having supplied catfish fingerlings.

\section{References}

1. Alborali L, Bovo G, Lavazza A, Cappellaro H, Guadagnini PF (1996) Isolation of an Herpesvirus in breeding catfish (Ictalurusmelas). Bull Eur Ass Fish Pathol 16: 134-137.

2. Parisi G, Terova G, Gasco L, Piccolo G, Roncarati A, et al. (2013) Current status and future perspectives of Italian finfish aquaculture. Aquaculture Committee of Association of Animal Production, Italy. Reviews in Fish Biology and Fisheries (1991-2013) Springer Netherlands.

3. Gobbo F, Cappellozza E, Pastore MR, Bovo G (2010) Susceptibility of black bullhead Ameiurusmelas to a panel of ranavirusisolates. Dis Aquat Organ 90: 167-174.

4. Melotti P, Gennari L, Roncarati A (1992) Ictalurusand other introduced species: possibilities and prospects in Europe. Workshop on aquaculture of freshwaterspecies (except salmonids). P. Kestemont and R. Billard (Eds.) EAS SpecialPublication No. 20, Ghent, Belgium, 19-20.

5. Melotti P, Roncarati A (2013) L'allevamentodeipescigatto e deiciprinidi. IIDivulgatore 1-2: 53-61 (In Italian).

6. Melotti P, Roncarati A (2009) State of the art and future trends of European and Italian aquaculture. Vet Res Commun 33: 9-13.

7. Martins CIM, Eding EH, Verdegem MCJ, Heinsbroek LTN, Schneider O, et al. (2010) New developments in recirculating aquaculture systems in Europe: A perspective on environmental sustainability.AquacultEng 43: 83-93.

8. Beckman WC (1948) Thelength-weight relationship factors for conversion between standard and total lengths, and coefficients of conditions for seven Michigan fishes. Trans Am Fish Soc 75: 237-256.

9. APHA (American Public Health Association, American Water Works Association and Water pollution Control Federation) (1995) Standard methods for the examination of water and wastewater, APHA, Washington DC.

10. Melotti P, Meluzzi A, Zucchi P, Giordani G, Cataudella S (1989) Seasonal effects on some serum and muscle enzymes of catfish (Ictalurusmelas) and common carp (Cyprinuscarpio). J Appllchthyol 5: 74-79.

11. Roncarati A, Dees A, Mordenti O, Angellotti L, Melotti P (2006) Welfare status of cultured seabass(Dicentrarchuslabrax L.) andseabream (Sparusaurata L.) assessed by blood parameters and tissue characteristics. J Appllchthyol 22: $1-10$.

12. Van de Nieuwegiessen PG, Olwo J, Khong S, Verreth JAJ, Schrama JW (2009) Effects of age and stocking density on the welfare of African catfish ClariasgariepinusBurchell. Aquaculture 288: 69-75.

13. Bergmeyer HU (1974) Methods of enzymatic analysis. Academic Press, New York, USA.

14. SAS Institute (1988) SAS/STAT Guide for Personal Computers. Version 6.03 Edn, SAS Institute Inc., Cary, NC, USA.

15. Novomeská A, Katina S, Copp GH, Pedicillo G, Lorenzoni M, et al. (2013) Morphological variability of black bullhead Ameiurusmelas in four non-native European populations. J Fish Biol 82: 1103- 1118.

16. Tucker CS, Boyd CE (1985) Water quality. Channel catfish culture. ElsevierScience Publishers, Amsterdam, The Netherlands.

17. Boyd CE, Gross A (1999) Biochemical oxygen demand in channel catfish Ictaluruspunctatus pond waters. J World AqSoc 30: 349-356.

18. Mc IWEM JAD (2006) Water quality and accelerated winter growth of European catfish using an enclosed recirculating system. Water and Environment Journal 20: 233-239.

19. David JA (2006) Water Quality and Accelerated Winter Growth OfEuropean Catfish Using An Enclosed Recirculating System. Water and Environment Journal 20:233-239.

20. Santa KD, Vinatea L (2007) Evaluation of respiration rates and mechanica aeration requirements in semi-intensive shrimp Litopenaeusvannamei culture ponds.AquacultEng 36: 73-80.

21. Roqued'Orbcastel E, Person-Le-Ruyet J, Le Bayon N, Blancheton JP (2009) Comparative growth and welfare in rainbow trout reared in re-circulating and flow through rearing systems. AquacultEng 40: 79-86.

22. Zhang S, Gu Li, Hui-Bi Wu, Xing-Guo Liu, Yan-Hong Yao, et al. (2011) An integrated recirculating aquaculture system (RAS) for land-based fish farming The effects on water quality and fish production. AquacultEng 45: 93-102.

23. Lin YF, Jing SR, Lee DY (2003) The potential use of constructed wetlands in a recirculating aquaculture system for shrimp culture. Environ Pollut 123: 107113.

24. Li G, Wu ZB, Cheng SP, Liang W, He F, et al. (2007) Application of constructed wetlands on wastewater treatment for aquaculture ponds. Wuhan Univ J Nat Sci 12: 1131-1135.

25. Roncarati A, Dees A, Pignata S, Meluzzi A, Sirri F, et al. (2009) Comparison of zootechnical performances, welfare condition and quality traits of hybrid striped bass (Moronechrysops $x$ Moronesaxatilis) reared in different Italian farms. It J Anim Science 8: 872-874.

26. Boyd CE, Queiroz JF (2001) Feasibility of Retention Structures, Settling Basins, and Best Management Practices in Effluent Regulation for Alabama Channel Catfish Farming. Reviews in Fisheries Science 9: 43-67. 